\title{
Når verdiar kolliderer
}

\author{
Det er uro i norsk sjukehusstell. \\ Fleire sjukehus juksar med dia- \\ gnosane. Dei set dyre diagnosar \\ på enklare plager. Så får sjuke- \\ huset meir pengar. Andre juksar \\ med ventelistene.
}

Det er ein underleg og tankevekkjande situasjon. Det ser ut til at fusk og fanteri har trengt seg inn i ein av dei sentrale verdiberarane i samfunnet vårt - helsestellet. Der skal liv og helse kome først og telje mest. I staden sit det folk inne i halvmørkret og hankar inn pengar dei ikkje har rett til, som dei så sit og gnukkar og tel.

Så kan ein stanse og undrast: Korleis kan det ha seg at tilsynelatande ærlege og skikkelege folk juksar, fiksar og triksar og går rundt etablerte regelverk utan utsikter til personleg vinning ved si lyssky og lovstridige verksemd? For dei som driv med dette, har personleg ingenting att for det. Det er ein underleg kriminalitet. Kvifor skjer det så?

Eg trur årsaka er å finne i styringsmodellen for sjukehusa. Sjukehusa er i dag organiserte som føretak. Dei heiter føretak og leiarane er føretaksleiarar. Føretaksleiarrolla har ein sterkt tankeformande kraft. Føretaksleiarane skal fremje og verne føretaket sitt, passe på økonomi, marknadsposisjon, teknologisk utvikling, alt det som sikrar liv og framtid for føretaket. Ein viktig del av jobben er å få organisasjonen med på dette, slik at alle dreg i same retning.

«My country, right or wrong,» sa den amerikanske sjøhelten Stephen Decatur ved ein bankett i 1816. Orda har fått evig liv.

Dette er essensen i føretaksleiarens tankeverd. Som ein magnetisk pol ligg føretakets beste framme i leia og styrer tankar og handlingar.

Føretak handlar om økonomi. Føretak skal skape overskot, avkasting og arbeidsplassar. Andre verdiar må underordne seg $\emptyset$ konomien. Utan orden i økonomien går føretaket under.

Med helseføretaka er det annleis. Helseføretaka skal, primært, ta vare på andre verdiar: liv og helse. Dei kan ikkje talfestast eller setjast pris på. Kva er det å forlengje eit menneskeliv med eitt år verdt i kroner og øre? Eller berge eit prematurt barn? Kva skal dette koste? For det kostar, i kroner og øre.

I helseføretaket ligg to verdisystem og fører ein dagleg krig. Verdisystema ligg på konstant kollisjonskurs.

Med føretaksmodellen er sjukehusa også blitt normale føretak, med budsjettrammer og økonomiske resultatkrav, med krav om å få mest mogeleg ut av pengane, med konkurranse i helsemarknaden (fritt sjukehusval). Resultatkrava/budsjettkrava i sjukehusføretaket er like strenge som i kva kommersielt føretak som helst.

I dette kollisjonspunktet sit då sjukehusleiaren. Om pasienten som klagar får flytte til eit anna sjukehus, som då får pengane tenesta kostar, vil det vere til skade for hans eige føretak. Han vil ha mindre pengar å produsere helse for. Andre vil få dei pengane han meinte var hans. Helsa vil bli produsert, men ein annan stad. For ein føretaksleiar er dette ein utåleleg tanke. Det skal det også vere. Ein konkurrent skal ikkje få pengane hans. Å la klagaren stikke til eit anna sjukehus og ta pengane med seg, ville vere dumt og klanderverdig av føretaksleiaren. Det ville vere til forderv for føretaket.

Det vi ser, er konsekvensen av at to diametralt ulike verdisystem lever og krev plass i ein og same organisasjon. Det blir det bråk av, krokvegar og kreative løysingar. Føretak som steller med kunst, som forlag og teater, er velkjende med dette kronglete landskapet. I desse føretaka skal økonomi og umålbare verdiar, som kunst og kvalitet, børs og katedral, leve saman. Det kan bli nokså kompromissfylt og ufredeleg til tider.

Det er vanskeleg å peike på gode løysingar her. Alle problem har ikkje gode løysingar. Medisinens aukande tilbod og vår stigande levealder garanterer at vi vil ha ressursmangel og prioriteringsstridi all framtid. Dei nødvendige pengane vil aldri kome.

No er helsestellet blitt så økonomisk stort og tungt at det må underleggjast same økonomiske styringssystem som andre store samfunnssektorar. Å heise flagg og vifte med spesielle og evige verdiar om liv og helse fører til lite. Her er helsestellet i same situasjonen som kyrkja var i si stordomstid i mellomalderen, då ho var rikare og hadde ein meir sentral posisjon i samfunnet enn ho har i dag. Kyrkja hadde ansvar for vår lagnad etter døden, i det evige liv, som i og for seg var viktig nok. Men ho var full av klerkar som førte bøker og heldt orden på pengane. Klerkane, økonomane, er komne for å bli i helsestellet, også som føretaksleiarar, med alt den rolla fører med seg av dilemma og konfliktar.

Vi bør kanskje bruke nokre tankar på å forstå situasjonen deira. Han er ikkje lett. Det er ikkje innlysande, ikkje eingong sikkert, at dei er kjeltringar. Ikkje alle, i alle fall.

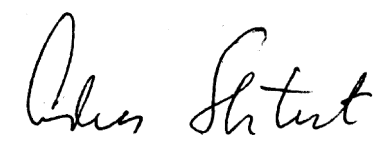

